\title{
New records of Micropezidae, Clusiidae and Periscelididae (Diptera: Acalyptrata) from Portugal
}

\author{
Jindřich Roháček, Rui Andrade, Ana Rita Gonçalves \& Jorge Mota Almeida
}

\begin{abstract}
New records of Micropezidae, Clusiidae and Periscelididae (Diptera: Acalyptrata) from Portugal. - Acta Mus. Siles. Sci. Natur. 65: 153-166, 2016.

Abstract: Records of 11 species of three families of acalyptrate Diptera, Micropezidae (4 species), Clusiidae (4) and Periscelididae (3) are given from Portugal. Seven species are new faunal additions to this country, viz. Neria cibaria (Linnaeus, 1761), Neria octoannulata (Strobl, 1899) (both Micropezidae), Clusiodes albimanus (Meigen, 1830), C. caledonicus (Collin, 1912), C. gentilis (Collin, 1912) (all Clusiidae), Periscelis (Myodris) piricercus Carles-Tolrá \& Verdugo Páez, 2009 and $P$. (Periscelis) sp. n. near P. winnertzii Egger, 1862 (Periscelididae). Distribution and biology of all recorded species are reviewed and supplemented with new information based on Portuguese material and notes on the taxonomy and variability of some species are appended.
\end{abstract}

Key words: Diptera, Micropezidae, Clusiidae, Periscelididae, new records, distribution, biology, Portugal.

\section{Introduction}

Micropezidae, Clusiidae and Periscelididae belong to families of Diptera Acalyptrata hitherto insufficiently studied in Portugal. Only a few representatives of these three families have previously been recorded from the country. The first concrete records of stilt-legged flies (Micropezidae) were published from Portugal only by Carles-Tolrá (2001a) who recorded a single female of Micropeza grallatrix Loew, 1868 from Santarém: Rio Maior and by CarlesTolrá $(2001 b, 2009)$ who reported on M. lateralis Meigen, 1826 found in several localities in districts of Guarda, Castelo Branco and Vila Real. However, M. lateralis was listed for Portugal already in the Catalogue of Palaearctic Diptera by Soós (1984, without concrete localities) and some of these records are also summarized in the catalogue by Carles-Tolrá (2002).

On the other hand, the Clusiidae have been encountered in Portugal only very recently: Carles-Tolrá \& Andrade (2011) presented a finding of single female of Clusiodes verticalis (Collin, 1912) from Porto: Avintes (Vila Nova de Gaia).

Similarly, the Periscelididae are also known from Portugal on the basis of a single record of two males of Periscelis (Myodris) annulata (Fallén, 1813) from Vila Real: Carvalhelhos (Carles-Tolrá 2009).

This study is mainly aimed at presentation of new data on the species of these three families based on material acquired recently by the authors during fieldwork in various parts of Portugal. A total of 7 species (Micropezidae - 2, Clusiidae - 3, Periscelididae - 2) are added to the regional fauna of Diptera and additional records of 4 other species of these families are also appended. New information on biology and general distribution of the species under study, obtained from the material examined, is presented and discussed. Original photographs of living specimens of some of these species are presented with the aim to enable better recognition of them in future field studies. 


\section{Material and methods}

Material. All the material examined was collected by authors of this study and was identified by J. Roháček. The majority of voucher specimens are preserved in $70 \%$ ethanol and deposited in the collection of R. Andrade, Porto, Portugal (RAP); the remaining specimens are in the collection of A. R. Gonçalves, Coimbra, Portugal (ARGC) and of J. Almeida, Viseu, Portugal (JM); some duplicates collected by R. Andrade were dried from ethanol during the course of this study and deposited in the collection of the Slezské zemské muzeum (= Silesian Museum), Opava (SMOC), similarly as are the dry-mounted specimens collected by J. Roháček during his expeditions to Algarve (2009, 2010).

Methods. Specimens of Micropezidae and Clusiidae were mostly collected by sweeping over vegetation in various (mainly forested) habitats; those of Periscelididae were usually netted from over bark of trees in oakdominated forests. Macrophotographs of living adults were taken by digital cameras Fujifilm FinePix S5500 and Fujifilm FinePix HS10 both with macro lens Raynox DCR-250 (R. Andrade), Canon EOS 30D with macro lens

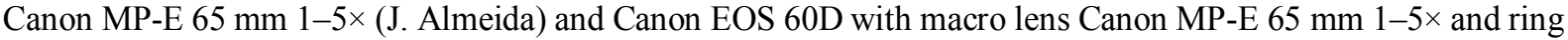
macro flash Canon MR-14EX (J. Roháček). Also habitats of some species in their Portuguese localities were documented by photography during the fieldwork.

Both dry-mounted and ethanol-preserved specimens were examined using two types of binocular stereoscopic microscopes (Reichert, Olympus). When necessary male and female terminalia were studied after detachment, treating in hot $10 \% \mathrm{KOH}$, washing in water and dissection of the whole abdomen in a drop of glycerine under a binocular microscope. After examination (also using a compound microscope JENAVAL in some cases), all parts of abdomen were transferred to a small plastic tube in glycerine and pinned below the respective drymounted specimen or put in the vial with ethanol-preserved specimen.

Label data are standardized and presented in full, including habitat and other biological information (if available).

Nomenclature. For Micropezidae the nomenclature used in Fauna Europaea is followed (Ozerov 2013); names of Clusiidae are treated according to Lonsdale \& Marshall (2007) and Roháček \& Merz (2013). Generic nomenclature of Periscelididae follows Mathis \& Rung (2011), thus the elevation of Myodris Lioy, 1864 to genus level by Papp \& Withers (2011) is not accepted.

\section{MICROPEZIDAE}

\section{Micropeza grallatrix Loew, 1868 (Fig 1)}

Material examined: PORTUGAL: Bragança, Vinhais, Vinhais, 41ํ51'01.3"N, 659'21.6"W, 980 m, sweeping vegetation, 10.ix.2014, 1요 R. Andrade leg. and photographed) (SMOC).

Biology: Largely unknown. Less frequent than M. lateralis; according to Freidberg (1984) adults can be mainly swept from oaks and occur in autumn (September - October). The female examined has been collected syntopically with $1 q$ of M. lateralis.

Distribution: A poorly known species widespread in the Mediterranean but also reaching southern parts of W. Europe, hitherto recorded from France, Germany, Italy, Portugal, Spain, Switzerland (Carles-Tolrá 2001a; Ozerov 2013) and Israel (Freidberg 1984).

Note. The female recorded above differs from Freidberg's (1984) redescription of $M$. grallatrix in having 1st antennal flagellomere orange to orange-brown (not blackish), the medial band on mesonotum widened while the adjoining brown band is reduced and pleura more darkened (see Fig. 1). These differences can be either due to colour variability or the populations in the western and eastern part of the Mediterranean are not conspecific. A detailed taxonomic study of material from all parts of the distribution range of $M$. grallatrix is needed to solve this problem.

\section{Micropeza lateralis Meigen, 1826 (Fig 2)}

Material examined: PORTUGAL: Porto, Valongo, Valongo, 4109'33.4"N, 8²9'05.6"W, 50-100 m, sweeping vegetation, 11.x.2010, 1 ; Vila Real, Montalegre, Pitões das Júnias (Parque Nacional da Peneda-Gerês), sweeping

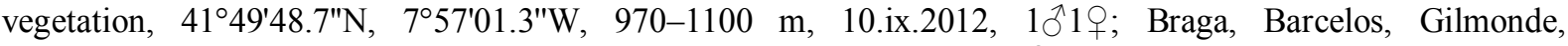
$41^{\circ} 30^{\prime} 43.0^{\prime \prime} \mathrm{N}, 8^{\circ} 38^{\prime} 57.0^{\prime \prime} \mathrm{W}, 25-50 \mathrm{~m}$, sweeping vegetation, 11.x.2012, 1 , , all R. Andrade leg. (RAP, SMOC); Guarda, Manteigas, São Pedro (Parque Natural da Serra da Estrela), 40²2'10.4'N, 7³3'04.4'W, 995 m, sweeping 


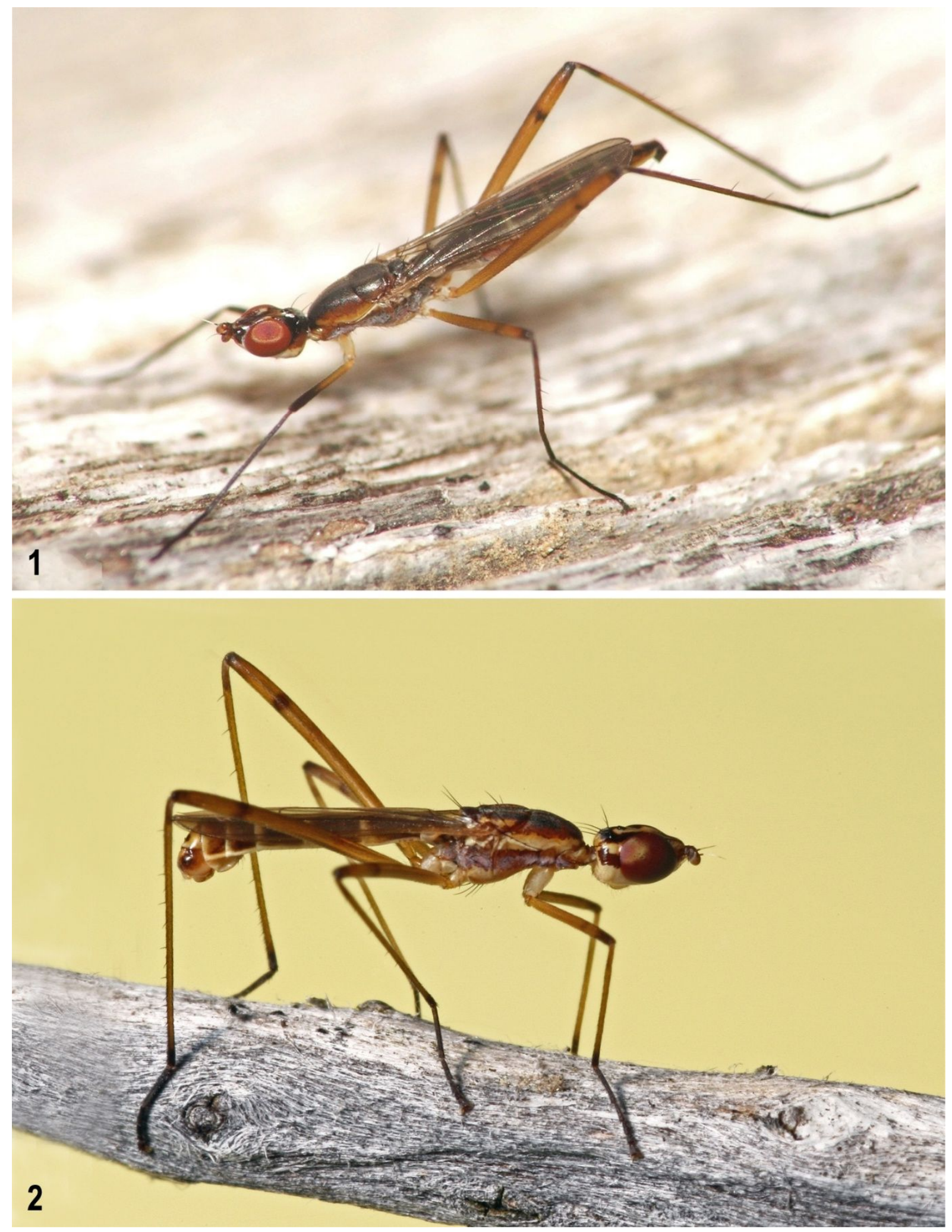

Figs 1-2: Micropeza species. 1 - M. grallatrix Loew, female, dorsolaterally; 2 - M. lateralis Meigen, male, laterally. Photo by R. Andrade (Fig. 1) and J. Almeida (Fig. 2). 
vegetation, 22.ix.2013, 2^^; Guarda, Seia, Loriga (Parque Natural da Serra da Estrela), 40¹9'41.26"N, 740'36.71"W, 901 m, sweeping vegetation, 3.ix.2014, 1\%; Guarda, Seia, Seia, São Romão e Lapa dos Dinheiros (Parque Natural da Serra da Estrela), 40²2'17.69"N, 740'33.16"W, 1022 m, sweeping vegetation, 4.ix.2014, 19 , all Ana Gonçalves leg. (ARGC); Bragança, Vinhais, Vinhais, 41 $51^{\prime} 01.3^{\prime \prime N}, 6^{\circ} 59^{\prime} 21.6^{\prime \prime} \mathrm{W}, 980 \mathrm{~m}$, sweeping vegetation, 10.ix.2014, 1\%; Bragança, Miranda do Douro, Vila Chã de Braciosa (Parque Natural do Douro Internacional), $41^{\circ} 25^{\prime} 29.8^{\prime \prime} \mathrm{N}, 6^{\circ} 18^{\prime} 29.4^{\prime \prime} \mathrm{W}, 602 \mathrm{~m}$, sweeping vegetation, 6.x.2015, 1의, both R. Andrade leg. (RAP); Records by photograph: Guarda, Seia, Sabugueiro (Parque Natural da Serra da Estrela), 40²1'54.3"N,

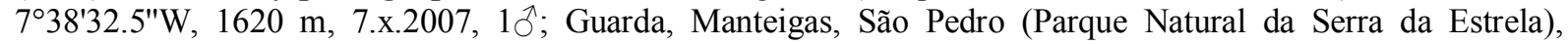
$40^{\circ} 19^{\prime} 56.0^{\prime \prime} \mathrm{N}, 7^{\circ} 34^{\prime} 14.6^{\prime \prime} \mathrm{W}, 1311 \mathrm{~m}, 29$.viii.2015, 10̄, both J. Almeida photographed.

Biology: Not precisely known. It seems to be a rather thermophilous species; according to Uffen \& Chandler (2010) adults can be regularly encountered in growths of broom (Cytisus scoparius) which may serve as the host plant of this species. Similarly as $M$. grallatrix also $M$. lateralis seems to be a distinctly autumnal species in Portugal with adults recorded from end of August to the first half of October (see material examined) in contrast to Neria octoannulata occurring exclusively in spring (see below).

Distribution: The species seems to be mainly distributed in temperate and southern parts of West Europe, reaching to Poland and the Czech Republic (S. Bohemia) in the east. It is known from Andorra, Czech Republic, Denmark, France, Germany, Great Britain, Netherlands, Poland, Portugal, Spain (Carles-Tolrá 2002; Beuk \& van der Goot 2002; Nowakowski 1991; Máca 2006, Ozerov 2013)

\section{Neria cibaria (Linnaeus, 1761)}

Material examined: PORTUGAL: Bragança, Bragança, Espinhosela, Cova de Lua (Parque Natural de Montesinho), 41 ${ }^{\circ} 3^{\prime} 08.2^{\prime \prime} \mathrm{N}, 6^{\circ} 49^{\prime} 37.4^{\prime \prime} \mathrm{W}, 792 \mathrm{~m}$, sweeping vegetation, 16.v.2015, 1ㅇ, R. Andrade leg. (RAP).

Biology: The larvae of $N$. cibaria are saprophagous; there is a rearing record from a grass-heap in England (Ferrar 1987). Adult flies occur (commonly in C. Europe) in forested or bushmargined banks of rivers, creeks and in boggy habitats (Roháček \& Barták 1990). They are predatory on small soft insects and can be found hunting them on leaves of bushes and low vegetation from April to September.

Distribution: Widespread in the Palaearctic Region, reaching from Portugal (new westernmost record) to the E. Palaearctic (Ozerov 2013). In Europe known from the following countries: Andorra, Austria, Belgium, Czech Republic, Denmark, Finland, France, Germany, Great Britain, Hungary, Ireland, Lithuania, Netherlands, Norway, Poland, Portugal, Russia (CET, NET), Slovakia, Spain, Sweden, Switzerland, Ukraine (Beuk \& van der Goot 2002; CarlesTolrá 2002; Chandler et al. 2000; Kahanpää \& Stuke 2014; Nowakowski 1991; Podènas \& Pakalniškiš 2000; Ozerov 2013).

Note. We did not find the original publication on which the Portuguese mainland record was included in Fauna Europaea (Ozerov 2013). Therefore the above specimen is considered the first documented record from Portugal.

\section{Neria octoannulata (Strobl, 1899) (Figs 3, 4)}

Material examined: PORTUGAL: Faro, Monchique, Monchique, Alcaria do Peso, 37019'53"N, 8³4'07"W, 500 $\mathrm{m}$, sweeping vegetation along brook, 3.iv.2009, 2ᄋ; same data but $37^{\circ} 20^{\prime} 09^{\prime \prime} \mathrm{N}, 8^{\circ} 33^{\prime} 58^{\prime \prime} \mathrm{W}, 450 \mathrm{~m}, 1$; ; Faro, Monchique, Monchique, Esgravatadouro env., $37^{\circ} 18^{\prime} \mathrm{N}, 8^{\circ} 31^{\prime} \mathrm{W}, 270-310 \mathrm{~m}$, sweeping vegetation along brook,

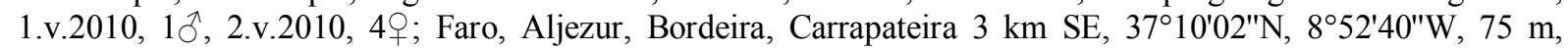
sweeping vegetation along brook, 3.v.2010, 19, all J. Roháček leg. (SMOC); Porto, Valongo, Valongo, $41^{\circ} 09^{\prime} 33.4^{\prime \prime} \mathrm{N}, 8^{\circ} 29^{\prime} 05.6^{\prime \prime} \mathrm{W}, 50-100 \mathrm{~m}$, sweeping vegetation, 26.iii.2012, $3{ }^{\Uparrow}$ (dried due to evaporated alcohol, mounted on pinned triangular cards); Aveiro, Estarreja, Canelas e Fermelã, 4043'22.7"N, 8³4'20.6"W, 4 m, sweeping vegetation, 13.iii.2012, $2 \overbrace{}^{\lambda} 2$; Guarda, Gouveia, Gouveia (Parque Natural da Serra da Estrela), $40^{\circ} 29^{\prime} 10.9^{\prime \prime} \mathrm{N}, 7^{\circ} 34^{\prime} 38.5^{\prime \prime} \mathrm{W}, 805 \mathrm{~m}$, sweeping vegetation, 25.iv.2013, 1웅 Viana do Castelo, Melgaço, Castro 

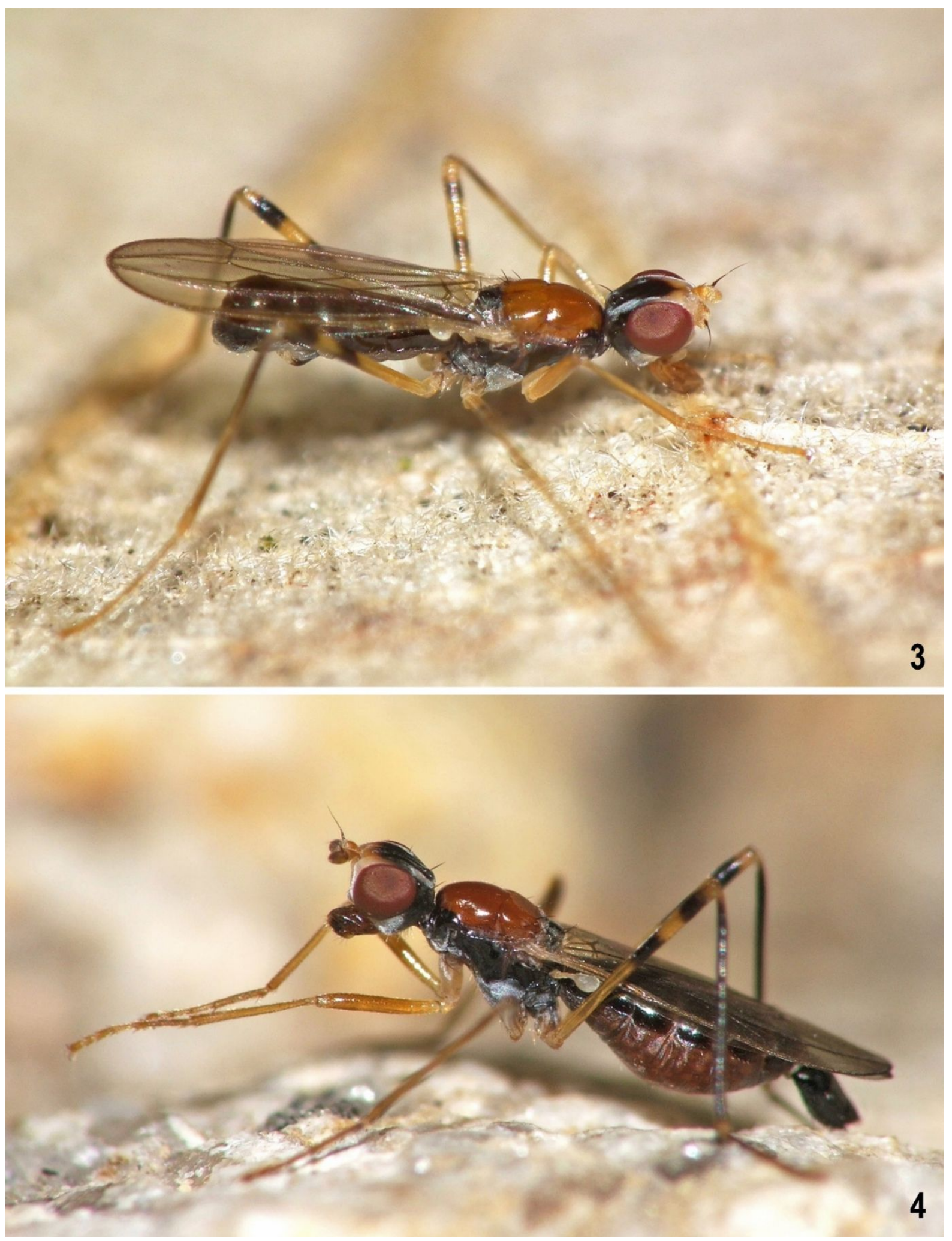

Figs 3-4: Neria octoannulata (Strobl). 3 - male, dorsolaterally; 4 - female, dorsolaterally. Photo by R. Andrade. 
Laboreiro e Lamas de Mouro, Cainheiras (Parque Nacional da Peneda-Gerês), 4201'32.8"N, $8^{\circ} 08^{\prime} 18.8^{\prime \prime} \mathrm{W}, 978$

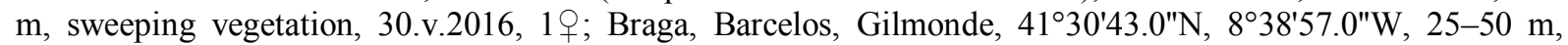
sweeping vegetation, 15.iv.2014, 1§ॅ; Vila Real, Mondim de Basto, Ermelo e Pardelhas, Varzigueto (Parque

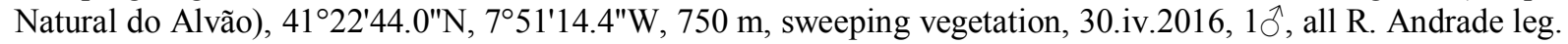
(RAP, SMOC).

Biology: The biology of this small Neria species remains undescribed. Like its closest relative, N. ephippium (Fabricius, 1794) (being absent in the Iberian fauna), it seems to preferably live in semi-open riparian habitats and can be swept from bushy vegetation on banks of small streams (see Fig. 5). The data from Portugal demonstrate it is a spring species, with adults flying in March - May (13.iii.-30.v.).

Distribution: Hitherto N. octoannulata has only been known from Spain (sf. Carles-Tolrá 2002; Ozerov 2013). First records from Portugal. The species seems to be restricted to the Iberian peninsula.

\section{CLUSIIDAE}

\section{Clusiodes albimanus (Meigen, 1830) (Fig. 7)}

Material examined: PORTUGAL: Bragança, Bragança, Espinhosela (Parque Natural de Montesinho), $41^{\circ} 53^{\prime} 52.2^{\prime \prime} \mathrm{N}, 6^{\circ} 51^{\prime} 11.2^{\prime \prime} \mathrm{W}, 763 \mathrm{~m}$, sweeping vegetation, 8.viii.2014, $1 \mathrm{O}^{\lambda}$ (red form), R. Andrade leg. (RAP).

Biology: Roháček (1995) considers this species eurytopic, occurring in various types of deciduous and mixed forests due to its ability to develop in rotting wood (in advanced state of decay) of a variety of broad-leaved tree species. For summary of rearing records see Rotheray \& Horsfield (2013) who also described preimaginal stages. Adults fly from May to October, with a distinct peak in June (Roháček 1995; Barrientos et al. 1996) while the autumnal occurrence can represent a second generation.

Distribution: The species is widespread in the Palaearctic Region, ranging from Portugal (first record, westernmost distribution limit) to Russia (East Siberia, Lonsdale \& Marshall 2007). Other European records are from Andorra, Austria, Belgium, Bulgaria, Czech Republic, Denmark, Finland, France, Germany, Great Britain, Greece, Hungary, Ireland, Italy, Lithuania, Netherlands, Northern Ireland, Norway, Poland, Romania, Russia (CET, NET, SET), Slovakia, Spain, Sweden, Switzerland, Ukraine (Dumčius \& Pakalniškiš 2004; Lonsdale \& Marshall 2007; Roháček \& Merz 2013).

Note. A variable species with body colour ranging from largely reddish yellow to predominantly blackish brown (like some its relatives, see below). It seems to be rare in the Mediterranean where it can be usually found in forested mountains (cf. Barrientos et al. 1996).

Clusiodes caledonicus (Collin, 1912)

Material examined: PORTUGAL: Faro, Monchique, Monchique, Alcaria do Peso, 37²19'53"N, 8³4'07"W, 500 m, sweeping vegetation along brook, 28.iv.2010, 10ึ, J. Roháček leg. (SMOC).

Biology: The life habits of this species are not precisely known. Apparently it can live both in deciduous and coniferous forests. Hitherto adults have only been reared from dead wood of aspen (Populus tremula) (Tuomikoski 1933) and pines (Pinus sp.) (Rotheray \& Horsfield 2013) but the species can surely utilize also that of other trees because $C$. caledonicus was also recorded from beech forests (Slovakia: Muránska planina - Roháček 2013). Adults occur in May - September but obviously also earlier in the south (April).

Distribution: This species is probably widespread in Europe but scarcely encountered in southern parts and hitherto apparently unrecorded from European Russia. It has been recorded from Austria, Belgium, Czech Republic, Denmark, Finland, Germany, Great Britain, Greece, Ireland, Italy (Sicily), Netherlands, Norway, Portugal, Slovakia, Spain, Sweden, Switzerland 

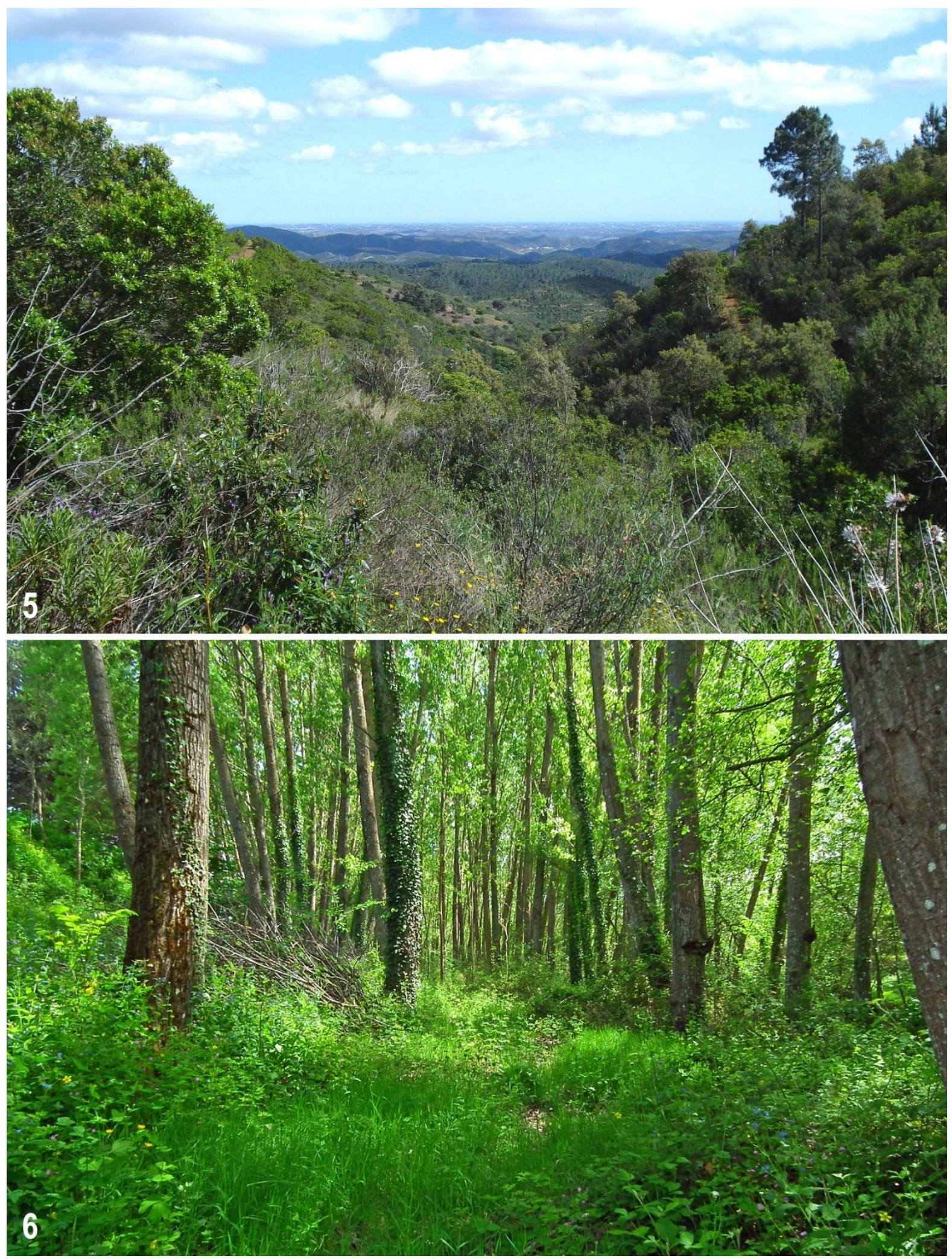

Figs 5-6: Habitats of Micropezidae and Clusiidae. 5-habitat of Neria octoannulata (Strobl), a shrubby vegetation along small brook (Esgravatadouro env.); 6 - habitat of Clusiodes gentilis (Collin), humid broad-leaved forest (Bragança, Castro de Avelãs). Photo by J. Roháček (Fig. 5) and R. Andrade (Fig. 6). 
(Lonsdale \& Marshall 2007; Roháček \& Merz 2013). The above (first) record from Portugal represents a new southwesternmost distribution limit of the species range.

Clusiodes gentilis (Collin, 1912) (Fig. 8)

Material examined: PORTUGAL: Porto, Valongo, Valongo, $41^{\circ} 09^{\prime} 33.4^{\prime \prime} \mathrm{N}, 8^{\circ} 29^{\prime} 05.6 " \mathrm{~W}, 50-100 \mathrm{~m}$, sweeping

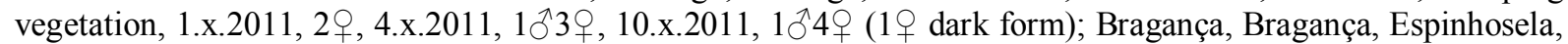
Cova de Lua (Parque Natural de Montesinho), 41 $1^{\circ} 53^{\prime} 08.2^{\prime \prime} \mathrm{N}, 6^{\circ} 49^{\prime} 37.4^{\prime \prime} \mathrm{W}, 792 \mathrm{~m}$, sweeping vegetation, 9.ix.2014, 10; Bragança, Bragança, Castro de Avelãs, $41^{\circ} 48^{\prime} 55.7^{\prime \prime} \mathrm{N}, 6^{\circ} 48^{\prime} 56.7^{\prime \prime} \mathrm{W}, 737 \mathrm{~m}$, sweeping vegetation, 10.v.2015,

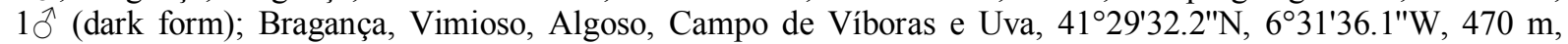
sweeping vegetation, 6.x.2015, 1§, all R. Andrade leg. (RAP, SMOC).

Biology: The study by Rotheray \& Horsfield (2013) demonstrates that $C$. gentilis can develop in rotten wood of various deciduous (Betula, Fagus, Salix, Ulmus) as well as coniferous (Pinus) trees. This explains the occurrence of the species in Cyprus where a series was found in Troodos Mts in a pine forest (Roháček 2004). In Portugal the species was only found in forest with predominant broad-leaved trees (Fig. 6). Adult flight period ranges from May to October but it can be different in north and south; interestingly most of the Portuguese records are from October.

Distribution: This species is probably more widespread than $C$. caledonicus ranging from Portugal (new, westernmost records) to the Tula region of Russia (CET) and Cyprus (Roháček 2004) albeit being extremely rare in Central Europe (Roháček 2013). Hitherto it has been recorded from Andorra, Belgium, Cyprus, France, Great Britain, Ireland, Netherlands, Northern Ireland, Poland, Russia (CET, NET), Slovakia, Switzerland (Lonsdale \& Marshall 2007; Roháček 2013; Roháček \& Merz 2013).

Note. Two specimens $\left(1 \jmath^{\uparrow}\right.$ q) examined have a largely dark brown thorax so resembling in coloration the dark form of $C$. albimanus. In contrast to the latter species where the dark form is prevailing over the red (yellow) form in most populations, the dark form of $C$. gentilis is obviously rare inasmuch as it has not been hitherto described in literature and Lonsdale \& Marshall (2007) even used the colour of scutum as a key character to separate C. gentilis (predominantly yellow) and C. caledonicus (predominantly black). Apparently, the colour variability of the scutum of $C$. gentilis is similar in all these species ranging from yellow with dark vittae to blackish brown although it seems to be less extensive in C. caledonicus. Therefore this character is not recommended to be used for the identification of these species.

\section{Clusiodes verticalis (Collin, 1912) (Fig. 9)}

Material examined: PORTUGAL: Faro, Monchique, Monchique, Alcaria do Peso, 37019'53"N, $8^{\circ} 34^{\prime} 07^{\prime \prime} \mathrm{W}, 500$ $\mathrm{m}$, sweeping vegetation along brook, 28.iv.2010, 1ㅇ, J. Roháček leg. (SMOC); Porto, Valongo, Valongo, $41^{\circ} 09^{\prime} 33.4^{\prime \prime} \mathrm{N}, 8^{\circ} 29^{\prime} 05.6^{\prime \prime} \mathrm{W}, 50-100 \mathrm{~m}$, sweeping vegetation, 12.v.2011, 19, 7.viii.2011, $1 \hat{\gamma}^{\circ}$; Porto, Vila Nova de Gaia, Avintes (Parque Biológico de Gaia), $41^{\circ} 06^{\prime} 00.0^{\prime \prime} \mathrm{N}, 8^{\circ} 33^{\prime} 35.3^{\prime \prime} \mathrm{W}, 50 \mathrm{~m}$, sweeping vegetation, 23.v.2011,

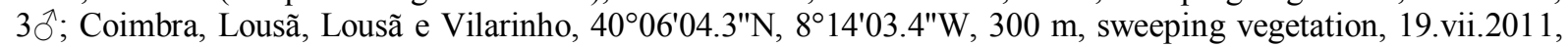
10 , all R. Andrade leg. (RAP).

Biology: Adults are known to preferably live in deciduous forests at lower altitudes (Roháček 1995) and fly from end of April (see material examined) to October (Lonsdale \& Marshall 2007). The rearing records by Withers (1985) and Rotheray \& Horsfield (2013) confirmed preference for dead wood of broad-leaved trees (Betula, Alnus, Fagus, Fraxinus, Salix) but the last mentioned authors also presented a rearing from a decaying Pinus branch.

Distribution: The species is widely distributed in Europe including its Mediterranean areas. Its distribution ranges from Portugal in the west (Carles-Tolrá \& Andrade 2011 and records listed above) to Israel in the east (Lonsdale \& Marshall 2007). There are records from Belgium, Czech Republic, Denmark, France, Great Britain, Hungary, Ireland, Israel, Italy (including Sicily), 

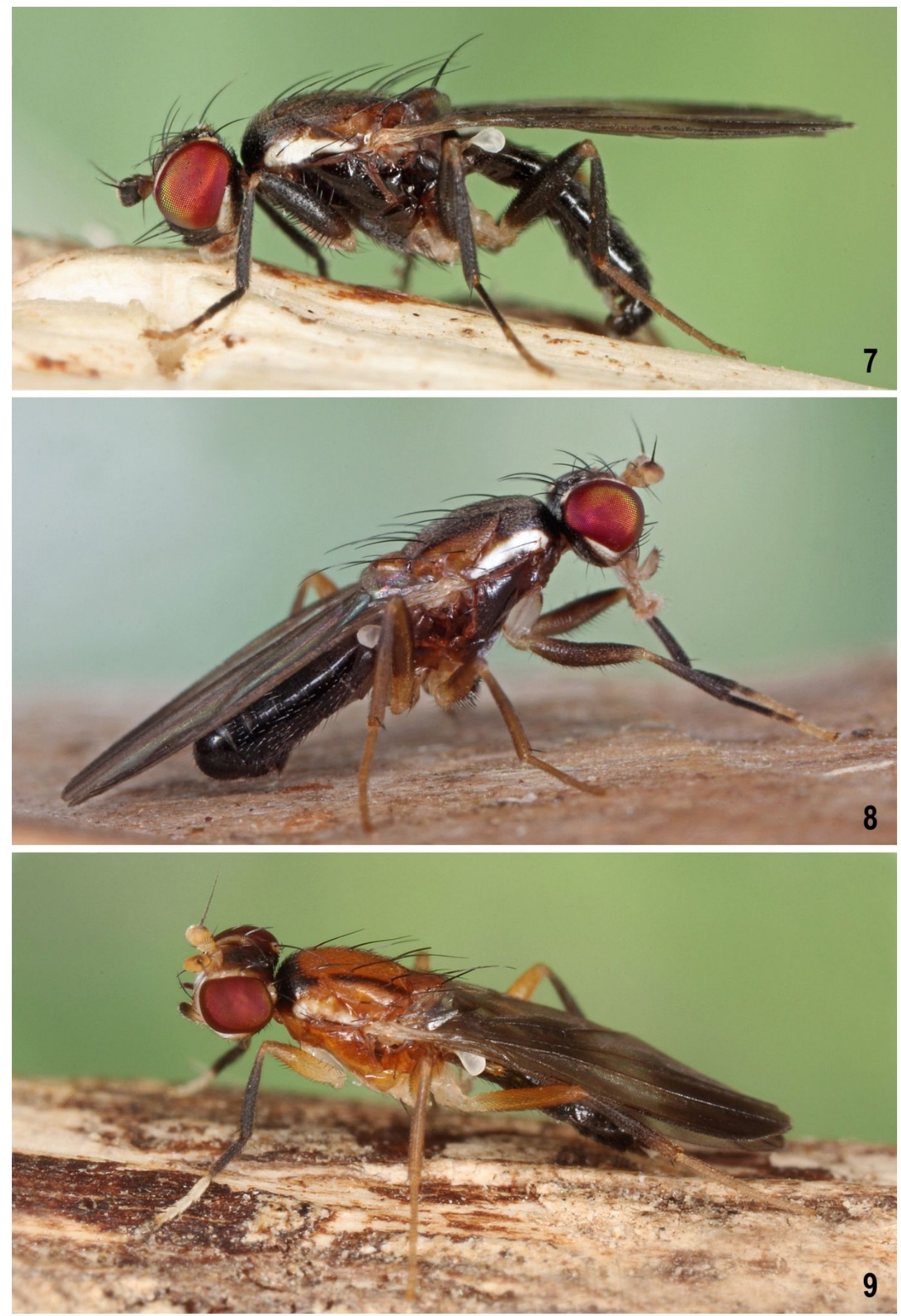

Figs 7-9: Clusiodes species. 7 - C. albimanus (Meigen), male, laterally; 8 - C. gentilis (Collin), male, laterally; 9 - C. verticalis (Collin), female, dorsolaterally. Photo by J. Roháček. 
Netherlands, Norway, Poland, Portugal, Slovakia, Spain, Sweden, Switzerland (Lonsdale \& Marshall 2007; Roháček \& Merz 2013). It seems that C. verticalis is the most frequently encountered species of Clusiidae in the Mediterranean subregion.

\section{PERISCELIDIDAE}

\section{Periscelis (Myodris) annulata (Fallén, 1813) (Fig. 10)}

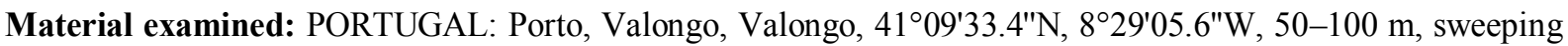
over bark of Quercus trees with sap runs, 1.x.2011, 1q, 4.x.2011, 1ð, 10.x.2011, 1q, 23.v.2013, 1, 1.vii.2013, $3 \jmath^{\wedge} 2$, , all R. Andrade leg. (RAP, SMOC); Portalegre, Marvão, Santa Maria de Marvão, 39 23'50.2"N, $7^{\circ} 21^{\prime} 52.3^{\prime \prime} \mathrm{W}, 616 \mathrm{~m}$, sweeping over bark of Quercus trees with sap runs, 21.ix.2014, 19, Ana Gonçalves leg. (ARGC); Aveiro, Estarreja, Canelas e Fermelã, 4043'22.7"N, 8³4'20.6"W, 4 m, sweeping over bark of trees with sap runs, 20.vii.2015, 1 , R. Andrade leg. (RAP).

Biology: Life habits of this species and trials with rearing its larvae are described by Papp (1998). Adults are associated with exudations of sap from living broad-leaved trees (usually in their crowns, cf. Bächli et al. 2006), preferentially of elms and oaks. Larvae living in sap runs require as food a fresh sap soaking the hard bark. They are able to stop development during the absence of sap flow falling into sleep mode (dormantia), particularly in summer, and continue it when oozing is restored. The life-history can be long because the larvae overwinter, sometimes twice, to pupariate and emerge in spring. Adults seasonal occurrence ranges from May to October.

Distribution: Widespread in Europe and Near East: recorded from Andorra, Austria, Bulgaria, Czech Republic, Denmark, Finland, France, Germany, Great Britain, Hungary, Israel, Italy, Netherlands, Poland, Portugal, Russia (CET, NET), Slovakia, Spain, Sweden, Switzerland (Carles-Tolrá 2009, 2013; Mathis \& Rung 2011; Papp \& Withers 2011).

\section{Periscelis (Myodris) piricercus Carles-Tolrá \& Verdugo Páez, 2009}

Material examined: PORTUGAL: Porto, Valongo, Valongo, 41 $1^{\circ} 09^{\prime} 33.4^{\prime \prime} \mathrm{N}, 8^{\circ} 29^{\prime} 05.6^{\prime \prime} \mathrm{W}, 50-100 \mathrm{~m}$, sweeping

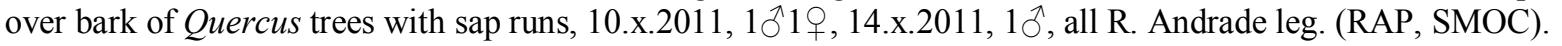

Biology: The type specimens $(4 \hat{\zeta}$ ) ) were collected by means of an interception trap in a Quercus suber forest in April - July (Carles-Tolrá \& Verdugo Páez 2009). The habitat agrees well with that of the 3 specimens recorded above but these were caught in October.

Distribution: The species has recently been described from southern Spain and is hitherto only known from the type locality (prov. Cádiz: Los Barrios), see Carles-Tolrá \& Verdugo Páez (2009) and Papp \& Withers (2011). First record from Portugal.

Note. The specimens examined agree perfectly with the original description (Carles-Tolrá \& Verdugo Páez 2009) and the redescription and key by Papp \& Withers (2011: Figs 39-44). They are generally darker than those of $P$. annulata and the terminalia of the males differ distinctly from those of all congeners.

\section{Periscelis (Myodris) spp.}

Material examined: PORTUGAL: Beja, Alvito, Alvito, 38 $14^{\prime} 20.36^{\prime \prime} \mathrm{N}, 7^{\circ} 57^{\prime} 27.44^{\prime \prime} \mathrm{W}, 202 \mathrm{~m}$, on debarked Quercus suber trunk, 17.iv.2011, 1q, R. Andrade leg. (originally J. Roháček det. as $P$. (M.) nr. piricercus); same data, 1ㅇ, J. Almeida leg. (RAP, JM). (originally J. Roháček det. as $P$. (M.) annulata).

Note. These 2 females are very faded due to preservation in poor alcohol, now unidentifiable. Therefore their data are listed separately. 

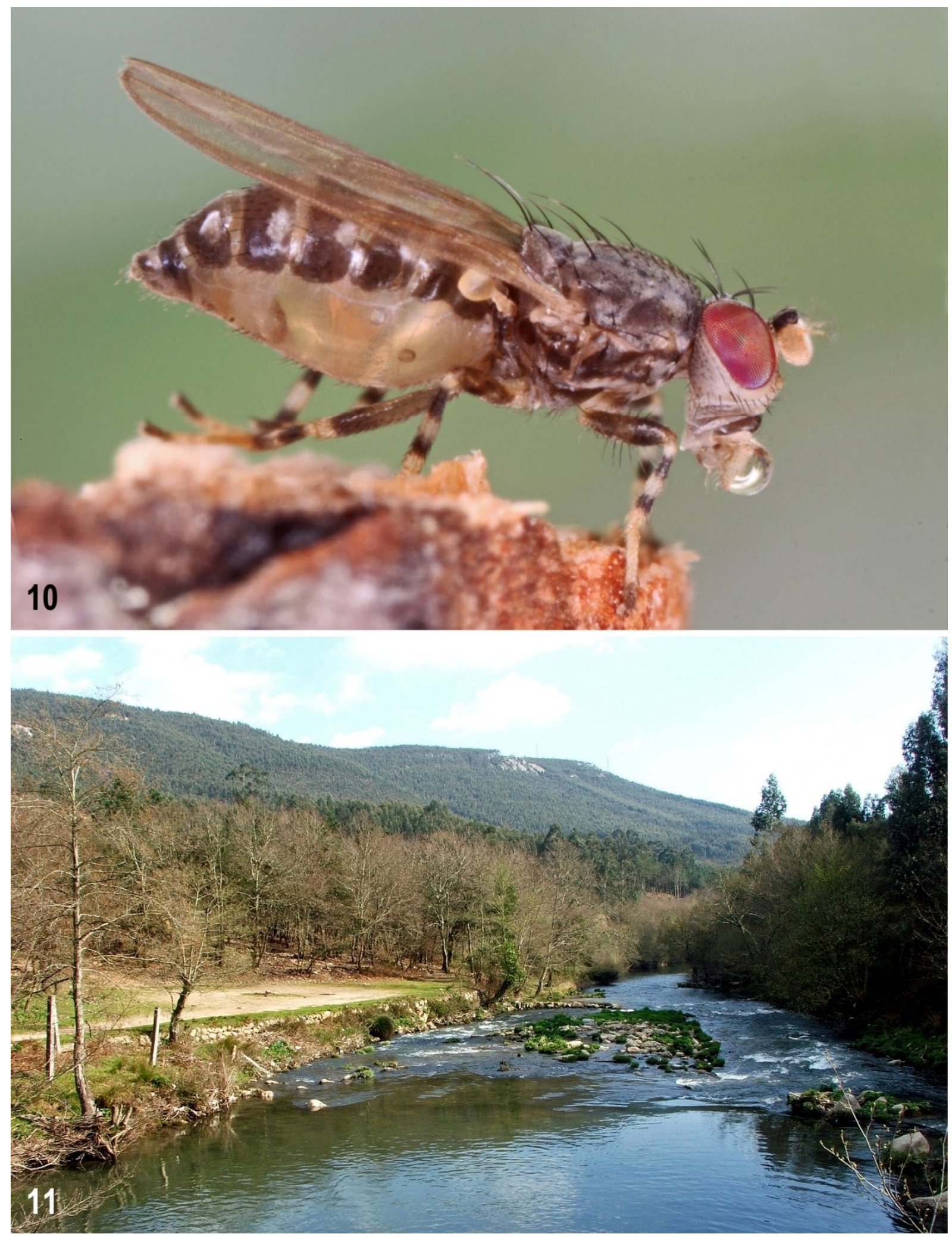

Figs 10-11: Periscelis species and their habitat. 10 - P. (Myodris) annulata (Fallén), female, laterally; 11 - habitat of three Periscelis species, oak forest (vernal aspect) near Valongo. Photo by J. Roháček (Fig. 10) and R. Andrade (Fig. 11). 


\section{Periscelis (Periscelis) sp. n. near P. winnertzii Egger, 1862}

Material examined: PORTUGAL: Porto, Valongo, Valongo, 41 ${ }^{\circ} 09^{\prime} 33.4 " \mathrm{~N}, 8^{\circ} 29^{\prime} 05.6^{\prime \prime} \mathrm{W}, 50-100 \mathrm{~m}$, sweeping

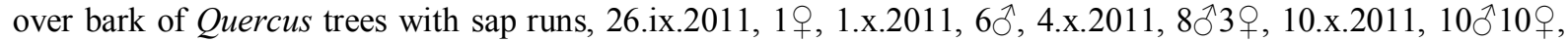
14.x.2011, 8 ${ }^{\wedge} 4$ 웅 Porto, Vila Nova de Gaia, Avintes (Parque Biológico de Gaia), $41^{\circ} 06^{\prime} 00.0^{\prime \prime} \mathrm{N}, 8^{\circ} 33^{\prime} 35.3^{\prime \prime} \mathrm{W}, 50$ m, sweeping over bark of Quercus trees with sap runs, 29.vi.2013, 1ठ; Braga, Vila Nova de Famalicão, Novais, $41^{\circ} 23^{\prime} 26.34^{\prime \prime} \mathrm{N}, 8^{\circ} 26^{\prime} 06.06^{\prime \prime} \mathrm{W}, 150 \mathrm{~m}$, sweeping over bark of Quercus trees with sap runs, 28.vi.2013, 1; Bragança, Bragança, Parâmio (Parque Natural de Montesinho), 4153'54.0"N, 651'16.3"W, 780 m, sweeping over bark of Quercus trees with sap runs, 21.vi.2015, 1ð̂, all R. Andrade leg. (RAP, SMOC); Portalegre, Marvão, Santa Maria de Marvão, 39²3'50.2"N, 7²1'52.3"W, 616 m, sweeping over bark of Quercus pyrenaica trees with sap runs, 21.ix.2014, 1ठำ

Biology: The species is associated with sap runs on oak trees like its closest congener, $P$. winnertzii and may have similar biology (cf. Papp 1998). Most adults were collected in autumn (September, October) but a few were also caught in June, see material examined.

Distribution: This undescribed species is a new addition to the fauna of Portugal and whole Europe.

Note. The above recorded specimens proved to belong to an unnamed species closely allied to $P$. winnertzii. This new species will be described in the near future (Roháček \& Andrade, in prep.).

\section{Discussion}

The new additions to the Portuguese fauna of Micropezidae, Clusiidae and Periscelididae presented here indicate that the local fauna of these families is in this country much richer than formerly known. The biodiversity of these and other Acalyptrate families in Portugal may eventually prove to be as high as is known in neighbouring Spain (cf. Carles-Tolrá HjorthAndersen 2002) as and when these flies are more thoroughly studied in field. The Clusiidae and Periscelididae, being associated with forested habitats, can be obtained by specially aimed collecting methods, and at least in Clusiidae we can expect several additional species in Portugal, at least those of Clusiinae, viz. Clusia flava (Meigen, 1830) and C. tigrina (Fallén, 1820), both known from Spain (Barrientos et al. 1996). An undescribed Periscelis species recorded above is the third species of Periscelididae in the Iberian Peninsula and we presuppose it will also be found in Spain. In Micropezidae there are two other species of Micropeza in Spain, viz. M. corrigiolata (Linnaeus, 1767) and M. hispanica Bigot, 1886 (Carles-Tolrá 2002). Both these species can be expected to be ascertained in Portugal in future; moreover, also the occurrence of some additional species of Calobatinae cannot be excluded in the Iberian Peninsula, particularly in the more humid areas of northern Portugal.

Acknowledgements: The authors would like to thank authorities of the Águas e Parque Biológico de Gaia, EM, SA and Ecoinside (Portugal) for support of this work, making possible the observations and collection of specimens by the junior author (RA). We are obliged to M. Barták, (Praha, Czech Republic), L. Papp and Z. Soltész (Budapest, Hungary) for loan of comparative material and help with identification; P. J. Chandler (Melksham, England) is thanked for the linguistic and scientific review of the manuscript. The research of the senior author (JR) was financially supported by the Ministry of Culture of the Czech Republic by institutional financing of longterm conceptual development of the research institution (the Silesian Museum, MK000100595), internal grant of the Silesian Museum No. IGS201607/2016. 


\section{References}

Barrientos J. A., Carles-Tolrá M. \& García-Romera C. (1996): Primeros datos de la familia Clusiidae (Diptera, Acalyptrata) para la fauna ibérica. - Boln. Asoc. Esp. Entomol. 20: 115-123.

Bächli G., Flückiger P. F, Obrist M. K. \& Duelli P. (2006): On the microdistribution of species of Drosophilidae and some other Diptera across a forest edge. - Mitt. Schweiz. Entomol. Ges. 79: 117-126.

Beuk P. L. Th. \& Goot V. S. van der (2002): Family Micropezidae. Pp. 217-218. In: Beuk P. L. Th. (ed.): Checklist of the Diptera of the Netherlands. KNNV Uitgeverij, Utrecht, 448 pp.

Carles-Tolrá M. (2001a): Nuevos datos sobre dípterors iberobaleares (Diptera: Orthorrhapha y Cyclorrhapha). - Boln. Asoc. Esp. Entomol. 25: 53-95.

- (2001b): Algunos dípteros nuevos para Portugal (Insecta, Diptera). - Zool. Baetica 12: 91-100.

- (2002): Micropezidae. P. 173. In Carles-Tolrá Hjorth-Andersen M. (2002): Catálogo de los Diptera de España, Portugal y Andorra (Insecta). Monografías S.E.A., Vol. 8, Sociedad Entomológica Aragonesa (SEA), Zaragoza, $323 \mathrm{pp}$.

- (2009): Nuevas citas de dípteros para la Península Ibérica y Portugal (Insecta, Diptera). - Boln. Soc. Entomol. Aragon. (S.E.A.) 45: 443-446.

- (2013): Fauna Europaea: Periscelididae. In Beuk P. \& Pape T. (eds): Fauna Europaea: Diptera, Brachycera. Fauna Europaea version 2.6, http://www.fauna-eu.org, Retrieved 29.07.2016.

Carles-Tolrá M. \& Andrade R. (2011): Algunos clúsidos, lauxánidos y psílidos de Portugal (Diptera: Clusiidae, Lauxaniidae y Psilidae). - Boln. Soc. Entomol. Aragon. (S.E.A.) 48: 489-490.

Carles-Tolrá M.\& Verdugo Páez A. (2009): Periscelis piricercus sp. n.: A new periscelidid species from Spain (Diptera: Periscelididae). - Heteropterus Rev. Entomol. 9(2): 101-104.

Carles-Tolrá Hjorth-Andersen M. (2002): Catálogo de los Diptera de España, Portugal y Andorra (Insecta). Monografías S.E.A., Vol. 8, Sociedad Entomológica Aragonesa (SEA), Zaragoza, 323 pp.

Chandler P. J., O’Connor J. P. \& Nash R. (2000): Diptera (Mycetophilidae, Empididae, Micropezidae, Drosophilidae, Sarcophagidae, Muscidae, Calliphoridae and Tachinidae) new to Ireland. - Dipterists Digest (second series) 7: 15-18.

Dumčius O. \& Pakalniškis S. (2004): New for Lithuania Diptera species found in 1993-2004. -New Rare Lithuan. Ins. Spec. Rec. Descr. Vilnius 16: 53-61.

Freidberg A. (1984): Acalyptratae of Israel: the family Micropezidae (Diptera). - Israel J. Entomol. 18: 11-20.

Kahanpää J. \& Stuke J.-H. (2014): Checklist of the superfamilies Conopoidea, Diopsoidea and Nerioidea of Finland (Insecta, Diptera). In Kahanpää J. \& Salmela J. (eds): Checklist of the Diptera of Finland. ZooKeys 441: 251-257.

Lonsdale O. \& Marshall S. A. (2007): Redefinition of the genera Clusiodes and Hendelia (Diptera: Clusiidae, Clusiodinae), with a review of Clusiodes. - Studia Dipterologica 14:117-159.

Máca J. (2006): Faunistic records. Micropezidae. In Kinkorová J. (ed.): Dipterologica bohemoslovaca Vol. 13. - Acta Universitatis Carolinae, Biologica 50: 149.

Mathis W. N. \& Rung A. (2011): World catalog and conspectus on the family Periscelididae (Diptera: Schizophora). Pp. 341-377. In Brake I. \& Thompson F. C. (eds): Contributions to the Systema Dipterorum (Insecta: Diptera). Myia 12, North American Dipterists Society \& Pensoft Publishers, Washington - Sofia - Moscow, 564 pp.

Nowakowski J. T. (1991): Micropezidae (Calobatidae, Tylidae). Pp. 170-171. In Razowski J. (ed.): Wykaz zwierząt Polski. Checklist of Animals of Poland. Vol. 2. Ossolineum, Wrocław - Warszawa - Kraków, 342 pp.

Papp L. (1998): Life-habits of the Central European species of Periscelididae (Diptera). - Folia Entomol. Hung. 59: 115-119.

Papp L. \& Withers P. (2011): A revision of the Palaearctic Periscelidinae with notes on some New World species (Diptera: Periscelididae). - Annls Hist.-Nat. Mus. Natn. Hung. 103: 345-371.

Podènas, S., Pakalniškis S. (2000): Supplement to the Diptera fauna of Lithuania. - Acta Zool. Lituanica 10(3): 20-26.

Roháček J. (1995): Clusiidae (Diptera) of the Czech and Slovak Republics: faunistics and notes on biology and behaviour. - Čas. Slez. Muz. Opava (A) 44: 123-140.

- (2004): New records of Clusiidae, Anthomyzidae and Sphaeroceridae (Diptera) from Cyprus, with distributional and taxonomic notes. In Kubík Š. \& Barták M. (eds): Dipterologica bohemoslovaca 11. - Folia Fac. Sci. Nat. Univ. Masaryk. Brun., Biol. 109: 247-264.

- (2013): The fauna of Acalyptrate families Micropezidae, Psilidae, Clusiidae, Acartophthalmidae, Anthomyzidae, Aulacigastridae, Periscelididae and Asteiidae (Diptera) in the Gemer area (Central Slovakia): supplement 1. - Čas. Slez. Muz. Opava (A) 62: 125-136.

Roháček J. \& Merz B. (2013): Fauna Europaea: Clusiidae. In Beuk P. \& Pape T. (eds): Fauna Europaea: Diptera, Brachycera. Fauna Europaea version 2.6, http://www.fauna-eu.org, Retrieved 20.07.2016. 
Rotheray G. E. \& Horsfield D. (2013): Development sites and early stages of eleven species of Clusiidae (Diptera) occurring in Europe. - Zootaxa 3619(4): 401-427.

Soós Á. (1984): Family Micropezidae (Tylidae). Pp. 19-24. In Soós Á. \& Papp L. (eds): Catalogue of Palaearctic Diptera. Vol. 9 Micropezidae - Agromyzidae. Akadémiai Kiadó, Budapest, 460 pp.

Tuomikoski R. (1933): Notizen über die Clusiiden (Dipt.) Finnlands. - Notul. Entomol. 13: 15-19.

Uffen R. \& Chandler P. (2010): Chapter 6. Associations with Fungi, Mycetozoa and Plants. Higher plants. Pp. 443-467. In Chandler P. (ed.): A dipterist's handbook (2nd Edition). The Amateur Entomologist Vol. 15, The Amateur Entomologist's Society, Brentwood, Essex, 525 pp.

Authors' addresses: Jindřich Roháček, Slezské zemské muzeum, Nádražní okruh 31, CZ - 74601 Opava, Czech Republic; e-mail: rohacek@szm.cz

Rui Andrade, Rua Calouste Gulbenkian 237 4H3, 4050-145 Porto, Portugal; e-mail: ruiamandrade@yahoo.com

Ana Rita Gonçalves, Rua do Brasil 338, 6 D, 3030-775 Coimbra, Portugal; e-mail: anagoncalvesm@gmail.com

Jorge Mota Almeida, Rua da Póvoa Dão n. 4, 3500-532 Silgueiros, Viseu, Portugal; e-mail: jorgemotalmeida@gmail.com 